\title{
Características de los elementos resistentes tipo sandwich construidos en materiales compuestos avanzados a partir de tejidos tridimensionales
}

\author{
Characteristics of sandwich-type structural elements \\ built of advanced composite materials from three \\ dimensional fabrics
}

Fecha de recepción: 7- III-97

Fecha de aceptación: 6-V-97
LUIS CASTEJÓN, MIGUEL A. JIMÉNEZ Y ANTONIO MIRAVETE ICMA - Dpto. de Ingeniería Mecánica. Universidad de Zaragoza

ESPAÑA
RESUMEN

Las estructuras tipo sandwich han demosirado ser alternativas de gran éxito para diversos campos de aplicación y, en concreto, en el sector de la construcción. Esto es gracias a sus excelente: propiedades de rigidez y resistencia especifica frente a cargas de flexión y otra larga lista de ventajas, a la cue pertenecen, por ejemplo, su buena resistencia a fatiga, resistencia al impacto, obtención de superficies liscas $y$ suaves, elevado aislamiento térmico y eléctrics, versatilidad de diseño y otras. Sin embargo, ias.s estructuras sandwich, tradicionales presenicin and problemática consistente en su tendencia a la delaminación, concentraciones de tensiones cparecidas ante la existencia de agujeros o uniones atorillakiss. resistencia al fuego. listos problemas son pol itcios gracias a la aplicación de estructuras novedosas tipo sandwich, construidas a partir de tejidos tridimensionales de materiales compuestos avanowdes, manteniéndose las ventajas existentes para las esiructuras sandwich tradicionales. De esie modo, cwiss nuevas estructuras pueden ser aplicadas en diversas. areas donde se venian aplicando las estructuras: sandwich convencionales, pero con mayor éxito. Lomo son muros, tabiques, suelos, bóvedas, cúpulas, estructuras de suelo y techo y viviendas.

\begin{abstract}
SUMMARY
Sandwich-type structures have proved to be alternatives of great success for several fields of application, and specially in the building sector. This is due to their outstanding properties of specific rigidity and strength against bending loads and other range of advantages like fatigue and impact resistance, attainment of flat and smooth surfaces, high electric and thermal insulation, design versatility and some others. However, traditional scindwich structures present problems like their tendeng. towards delamination, stress concenirations in bores or screwed joints, and fire resistance. These protlons are allaviated thanks to the use of new sandwich shatures built using three dimensional structures of advanced composite materials, maintaining the present ativantoges for more traditional sandwich structures. At this rite, these new structures can be applied in several aness where conventional sandwich structures used to be like walls, partitions, foor ond ceiling struciures, domes, vauls and dwellings, but with greater success.
\end{abstract}




\section{INTRODUCCIÓN}

La historia de la ciencia nos enseña que el desarrollo de las llamadas altas tecnologías ha estado tradicionalmente vinculado a la industria militar, aunque durante los últimos años se puede constatar que es, también, el mundo de la alta tecnología deportiva el que ha representado un papel muy importante en este desarrollo. La historia nos enseña, asimismo, que los resultados de estos desarrollos tecnológicos llegan ,más tarde o más temprano, a estar presentes en todos los ámbitos de la sociedad moderna y, por supuesto, en un sector tan representativo como es el de la construcción.

En este sentido, la segunda mitad del siglo $X X$ se viene caracterizando como la época de los productos sintéticos, es decir, plástico, fibras artificiales, cauchos sintéticos, materiales compuestos y adhesivos sintéticos.

Para aplicaciones civiles o estructurales, en las que tanto la resistencia como la rigidez del material son críticas, si se desea aplicar los materiales nombrados previamente, se debe combinar el polímero con otros materiales para obtener, de este modo, materiales compuestos, cuyas propiedades superen a las de sus constituyentes.

El componente más utilizado comunmente se encuentra en forma de particulas o en forma fibrosa. En ambos casos, las partículas o fibras de un material con alta resistencia y rigidez están embebidos o adheridos entre si mediante una matriz continua (polímero) de bajo módulo de elasticidad.

En la industria de la construcción, la fibra de vidrio, carbono, aramida o la combinación de las mismas y el polímero de poliester o epoxi se utilizan para formar un material compuesto fibroso. El resultado recibe el nombre de plástico (poliester o epoxi) reforzado con fibra de vidrio (PRFV), o, más usualmente, polimero reforzado con fibra (PRF).

La historia de la utilización de los polímeros y materiales compuestos en la construcción se inició durante la segunda guerra mundial, con la fabricación de las primeras casetas para equipos de radares electrónicos, utilizándose, en los 50, para fabricar láminas translúcidas. Sin embargo, el principal acontecimiento de interés respecto al material compuesto se produjo en los años 60 , debido a sus especiales características.

Una de las soluciones estructurales que ha permitido la obtención de magnificas propiedades de rigidez y resistencia especifica frente a flexión, ha sido el desarrollo de una tecnologia específica de materiales

\section{INTRODUCTION}

History of Science shows us that the development of the so-called high technologies has been traditionally related to military industry. Ilowever, during the last few years, high technology applied on sports has performed a major role in this development. IIistory shows us as well that the outcome of these technological developments are sooner or later present in every day life and specially in a field as representative as the building secior.

In this sense, the second half of the XX century, is characterised as the era of synthetic products, that is. plastic, artificial fibres, synthetic rubier. composite materials and sinthetic glues.

lor civil or structural applications. where resistance as well as rigldity of the material are critical, in order to use the named materials. the polymer should be combined with other materials to produce composite materials which properties excel those of the constituents:

The most common component is found in form of particles or fibre. In both cases, these fibres or particles of a material with high rigidity and strength are embedded or stuck together by means of a continuous matrix(polymer) of low Young's modulus.

In the building industry. glass and carbon fibre. aramida or a combination of some of them and the polymer of epoxy or polyester are used to produce a fibre composite material. The result is given the name of glass fibre reinforced plastic (polyester or epoxiv((ilRP) or more usually. fibre reinforced polymer $(1 \% R I)$.

The history of the use of polymers and composite materials in the building industry started during the II world war, with the production of the first sheds for radar equipment, and in the fifties they were used to produce trans/ucent sheets. Ilowever, the main breakthrough of interest regarding composite materials occurred in the sixties:

(One of the structural solutions which allowed the attaining of outstanding properties of specific rigidity and strength against bending moment, has been the development of a special technology of composite 
compuestos que se conoce con el nombre de paneles sandwich, en la que se combinan distintos tipos de materiales.

Sin embargo, la tecnología de paneles sandwich, aun aportando importantes cualidades de rigidez y ligereza, tradicionalmente ha presentado un punto débil en lo que a la conexión de los elementos que la constituyen se refiere.

Para paliar este problema, en los últimos años se ha desarrollado una tecnología que permite la configuración de un nuevo tipo de paneles sandwich, construidos a partir de tejidos tridimensionales.

\section{CONSTITUCIÓN DE LAS ESTRUCTURAS TIPO SANDWICH}

Un sandwich estructural está constituido, básicamente, por los tres elementos mostrados en la Figura 1 y que son citados a continuación :

-Dos pieles o láminas delgadas y resistentes que pueden ser de distintos espesores y materiales.

-Un núcleo grueso y ligero que separa las pieles, a la vez que les confiere estabilidad y cuya mision es la de transmitir, mediante cortadura, acciones mecánicas de una piel a otra.

-Un elemento adhesivo que conecta pieles y núcleo, capaz de transmitir cargas axiles y de cortadura entre las partes que une

No obstante, los espesores de cada uno de estos tres elementos constituyentes de un sandwich deben de estar comprendidos dentro de unos determinados limites. materials known as sandwich sheets, where different types of materials are combined.

However, the technology of sandwich structures, although providing for important qualities of rigidity and lightness, has traditionally presented a weak spot regarding the connection of the constituent elements.

In order to diminish this problem, during the last few' years, new technology has been developed towards the production of new type of sandwich structures built of 3-1) fabrics.

\section{CONSTITUTION OF SANDWICH STRUCTURES}

A structural sandwich is basically composed of the three elements shown in Figure I and quoted hellow:

-Two thin and strong lamina or skins whose constituent materials and thickness can be varied.

-1 light and thick core that keeps both skins apart. provides stability and where shear stresses transfer the load from one skin to another.

-1 sticking substance that joints skins and core, able to transfer axial and shear stresses between the connected parts.

levertheless, the thicknesses of every one of the three elements have to be confined within certain limits. The

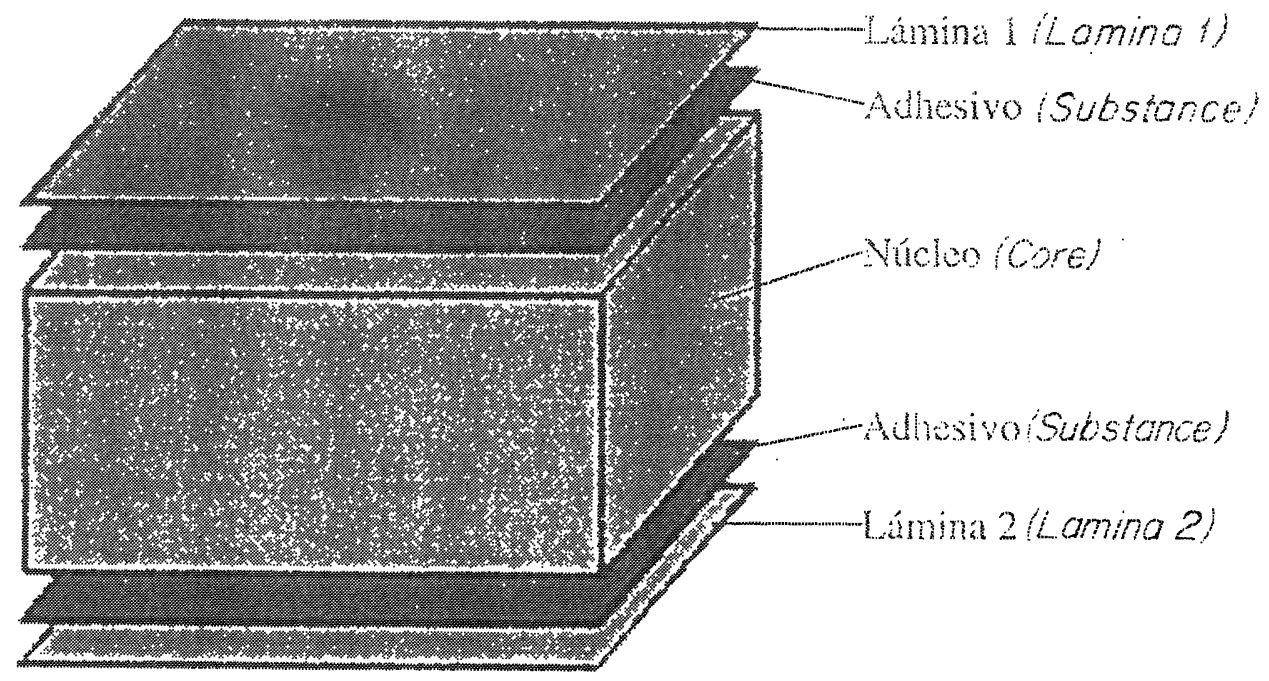

Fig, 1.- Partes constitutivas de una estructura convencional tipo semdwich.

lïg. l.- ('onstitutwe' parts of a connentional sandwich structure. 


$$
10 \leq \frac{t_{n}}{t_{p}} \leq 100
$$

Donde $t_{n}$ es el espesor del núcleo y $t_{p}$ es el espesor de las pieles.

Además, con objeto de que cada una de las partes trabaje bajo los esfuerzos para los que ha sido diseñada, se debe cumplir que : where $t_{n}$ is the thickness of the core and $t_{p}$ is the thickness of the skin.

Moreover, in order to make every part work under the stresses considered in design. the dimensions should comply with:

$$
\frac{\mathrm{t}_{\mathrm{n}}}{\mathrm{H}} \leq 0,1
$$

Donde $\mathrm{H}$ es la longitud menor de las aristas que delimitan las dimensiones del sandwich.

La estructura sandwich es diseñada con objeto de que los revestimientos o pieles absorban los esfuerzos de flexión y cargas aplicadas en el plano. Son los que proporcionan prácticamente la totalidad de la rigidez a flexión del conjunto. El núcleo separa las pieles entre si para aumentar la inercia a flexión y soporta los esfuerzos de cortadura. Al aumentar la distancia entre pieles se obtiene un aumento cuadrático de la rigidez a flexión.

La utilidad básica de la estructura sandwich radica en el ahorro de peso que se puede obtener para un determinado nivel de rigidez a flexión. Esto se puede ver en la Tabla 1.

\section{TABLA I (TABLE /)}

Comparación de precios y pesos relativos de diferentes tipos de estructuras con la misma rigidez a flexión

(Comparison of relative prices and weights for different types of structures for a given value of bending rigidity)

\begin{tabular}{||c|c|c||}
\hline $\begin{array}{c}\text { Estructura } \\
\text { (Structure) }\end{array}$ & $\begin{array}{c}\text { Peso relativo } \\
\text { (Relative weight) }\end{array}$ & $\begin{array}{c}\text { Precio relativo } \\
\text { (Relative price) }\end{array}$ \\
\hline Chapa de acero (Steel sheet) & 16 & \\
\hline Chapa de alumino (Aluminium sheet) & 10 & 1 \\
\hline Contrachapado (Plywood) & 5 & 1 \\
\hline $\begin{array}{c}\text { Sandwich de honeycomb de aluminio-piel de aluminio } \\
\text { (Aluminium honeycomb-aluminium skin sandwich) }\end{array}$ & 1 & 1,57 \\
\hline $\begin{array}{c}\text { Sandwich de nomex-piel de fibra de vidrio } \\
\text { (Nomex-fibreglass skin sandwich) }\end{array}$ & 1,12 & 2,42 \\
\hline $\begin{array}{c}\text { Sandwich de honeycomb de aluminio-piel de Kevlar } \\
\text { (Aluminium honeycomb-Kevlar skin sandwich) }\end{array}$ & 0,86 & \\
\hline $\begin{array}{c}\text { Sandwich de honeycomb de alumınio-piel de carbono } \\
\text { (Aluminium honeycomb-carbone skin sandwich) }\end{array}$ & 0,69 & \\
\hline
\end{tabular}


Otras ventajas de este tipo de estructuras son :

- Excelente resistencia específica.

- Buena resistencia a fatiga, debido a la no existencia de concentradores de tensiones.

- Obtención de superficies lisas y suaves, que pueden ser recubiertas por algún material embellecedor, siendo esta característica de especial importancia para aplicaciones en el sector de la construcción.

- Resistencia al impacto.

- Elevado aislamiento térmico y acústico, especialmente con núcleos de espuma de poliuretano.

- Versatilidad de diseño.

- Bajo coste y tiempo de fabricación, gracias al uso de uniones adhesivas

Sin embargo, estas estructuras convencionales tipo sandwich, presentan una problemática consistente en los siguientes aspectos :

-Delaminación. Tendencia a la separación por cortadura o pelado de la unión entre pieles y núcleo, que es función de las características del adhesivo empleado.

-Concentración de tensiones en agujeros o uniones atornilladas. Este tipo de problema se presenta, de forma más patente, en paneles sandwich con nucleos de honeycomb, los cuales son, de por sí, discontinuos.

\section{ELEMENTOS TIPO SANDWICH CONSTITUIDOS POR NUEVOS TEJIDOS TRIDIMENSIONALES EN MATERIALES COMPUESTOS}

La problemática antes citada de las estructuras convencionales tipo sandwich se puede paliar por medio de nuevas tecnologías de tejeduria tridimensional, capaces de fabricar preformas de este tipo de materiales compuestos avanzados

Un tejido tridimensional constituido por materiales compuestos se puede definir como todo tipo de tejido en el que se pueden encontrar fibras orientadas en las tres direcciones del espacio. Estas fibras se impregnan con las resinas adecuadas en función de los requerimientos exigidos por la aplicación final.

Estos tejidos tridimensionales, utilizados en la elaboración de paneles sandwich, se componen, básicamente, de dos tejidos planos tradicionales que
Other advantages of this type of structures are:

- Outstanding specific strength.

- Good fatigue resistance, due to the absence of stress concentrators.

- Attainment of flat and smooth surfaces, that can be covered with embellishing material, being this characteristic of special importance for applications in the building sector.

- Impact resistance.

- IIigh thermal and acoustic isolation, specially with polyurethane foam core.

- Design versatility.

- Low cost and manufacturing time, thanks to the use of adhesive joints.

However, these conventional sandwich structures, present the following series of problems:

-I Delamination. Tendency towards separation by shear or peeling of the joint between skins and core. depending on the characteristics of the adhesive used. -('oncentration of stresses in bores or screwed joints. This kind of problem appears more clearly in sandwich sheets with honeycomb cores, which discontinuity is obvious.

\section{SANDWICH STRUCTURES BUILT OF NEW THREE DIMENSIONAL FABRICS OF COMPOSITE MATERIALS}

The problems found in conventional structures can be alleviated applying new technologies of 3-D weaving able to produce sandwich structures with this kind of advanced composite materials.

A 3-I) fabric made up of composite materials can he defined as any kind of fabric where fibres can be found oriented in all three space directions: These fibres are impregnated with the appropriate resins depending on the requirements of the final application.

The three dimensional fabrics used in sandwich plates are composed of two conventional plane fabrics that constitute the skins, joint together by a series of fihres 
constituyen las pieles del mismo, interconectados entre sí por medio de un conjunto de fibras llamadas "piles", que van de uno de los tejidos de las pieles al otro. Estas fibras son las que confieren al tejido la característica de tridimensionalidad. Esto puede apreciarse en la Figura 2.

La gran ventaja de este tipo de tejido consiste en que los piles pertenecen a ambas pieles. Es decir, un pile es un conjunto de fibras que, durante el proceso de tejeduria, se le hace pertenecer a uno de los tejidos, viajar hasta el otro, pertenecer a este último $\mathrm{y}$, de nuevo, volver al primero, y así sucesivamente.

Adicionalmente se tiene la ventaja de que todo el proceso de tejeduría de los dos tejidos que forman la pieles y de los piles de conexión se realiza en único paso. Lo cual ha permitido la reducción de elaboración de estructuras sandwich. Además, el proceso es totalmente versatil, ya que es posible fabricar estos tejidos utilizando prácticamente cualquier tipo de fibra convencional (incluso carbono), se puede controlar la longitud de los piles (4 a $60 \mathrm{~mm}$ aproximadamente) y además se puede controlar la densidad de los mismos por metro cuadrado.

La posibilidad de introducir como variables en el proceso de fabricación la longitud de los piles, asi como densidad de los mismos, espesor de pieles y materiales utilizados, hace que los tejidos tridimensionales sean candidatos a su utilización como alternativa a los paneles sandwich convencionales, superándolos en prácticamente todos los campos (Fig. 3).

En resumen, se puede citar que la existencia de los piles de unión entre los tejidos que constituyen las pieles, le proporcionan a los tejidos tridimensionales una resistencia frente a delaminación por cortadura o pelado muy superior a la presentada por las estructuras sandwich called piles travelling from one skin to another. These fibres give the resulting fabric the characteristic of three dimensionality, as shown in ligure 2.

The major advantage of this type of fabric is that the piles belong io both skins. A pile is, then, a series of fibres that in the waving process belongs first to one of the skins then to the other, again to the first and this repeats during the process.

Additionally, the weaving process of skins and piles is made in just one step, thus, the reduction in manufacturing time is indeed another importani advantage. Moreover, the process is versatile. heing ossible to produce these fabrics using almost any kind of conventional fibre (including carbon), and the length of piles can be controlled as well as their idensity per squared metre.

The possibility of introducing the length of the piles as a parameter in the manufacturing process. as well as the density, skin thickness and materials, makes 3-1) fabrics candidate for their use as alternative of conventional sheets, excelling them in every respect (Fig. 3).

To sum up, the presence of joining piles between the fabrics that constitute the skins provide the 3-I) fabrics for a delamination resistance against shear stresses: and peeling much higher than that of conventional

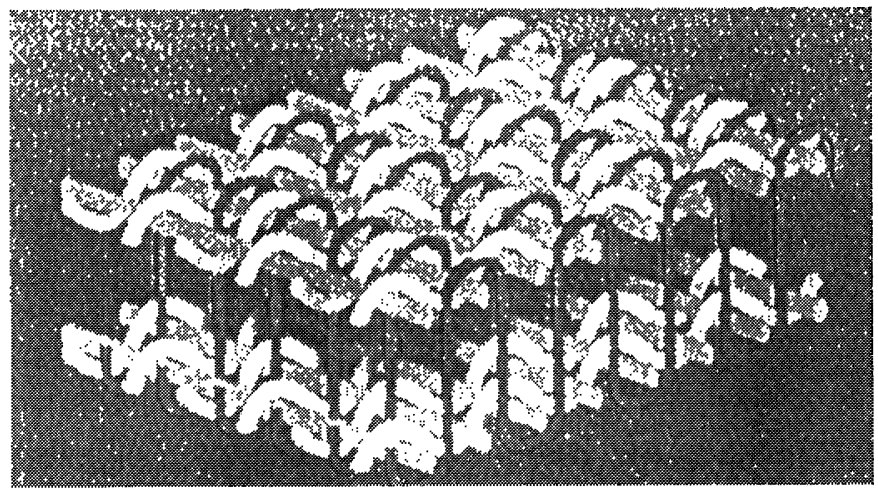

lig. 2.- Lsquema de una estructura samdwich en materiales compuestos. constituida a partir de un tejido tridimensional.

Hig. I.- Sketch of a sandwich structure in composite materals built of 3-I) fabrics. 

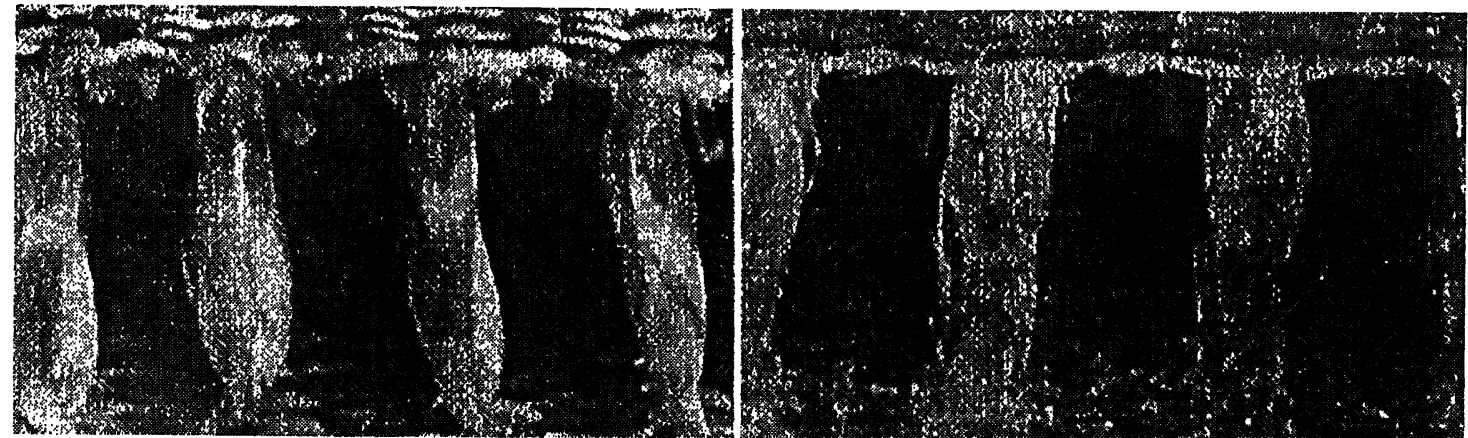

Fig. 3.- Detalle de un tejido tridimensional seco e impregnado.

Fig. 3.- Close examination of a 3-D fabric dry and impregnated.

convencionales, lo cual es su principal inconveniente. De igual modo, este tipo de estructura tridimensional tipo sandwich supera con creces a las estructuras tradicionales de este tipo en términos de resistencia, frente a las concentraciones de tensiones debidas a la existencia de agujeros y uniones atornilladas.

Otro aspecto en el que los nuevos paneles sandwich tridimensionales superan a los tradicionales, es en cuanto a la resistencia al fuego. Puesto que en el caso de una eventual pérdida de la espuma que forma el núcleo por efecto de la temperatura, todavía conservan gran parte de su integridad estructural, gracias a la presencia de los piles.

\section{APLICACIONES DE LAS ESTRUCTURAS SANDWICH EN EL SECTOR DE LA CONSTRUCCIÓN}

El campo de aplicación de las estructuras tipo sandwich $\mathrm{y}$, sobre todo, de las estructuras tridimensionales tipo sandwich construidas en materiales compuestos es muy amplio en el sector de la construcción

Pueden ser utilizadas en la fabricación de muros y tabiquería en general, por medio de la creación de superficies lisas o curvadas para revestir y/o aislar los muros de edificios, oficinas, fábricas o instalaciones deportivas, pudiendo ser utilizadas para

- Panelado, aislamiento externo sin armazón, compuesto del panel y el material aislante, fijados directamente al muro.

- Cubierta.

- Revestimiento.

- Muros cortina. sandwich structures. This type of 3-D sandwich structure excels by far conventional structures in terms of resistance against stress concentrations due to the presence of bores and screwed joints.

Other respect which new 3-D sandwich sheets excel conventional ones is in the fire resistance. Since in case of an eventual loss of the foam that constitutes the core caused by high temperature, it still retains most of their structural integrity due to the presence of the piles.

\section{APPLICATION OF SANDWICH STRUCTURES IN THE BUILDING SECTOR}

The field of application of sandwich structures and specially of 3-1).sandwich structures is broad in the building sector.

They can be used in the manufacture of walls and partitions in general, by means of flat or curved surfaces to cover and/or isolate the walls of any buildings like office buildings, factories or sport facilities. They can be used for :

-Panelling, outdoor isolating without armour, composed of a panel and the isolating material fitted directly on the wall.

- Coverings

- Surfaces

- ('urtain walls 
Las nuevas estructuras sandwich tridimensionales son especialmente indicadas en la fabricación de suelos gracias a sus excelentes propiedades en términos de rigidez y resistencia específica frente a cargas de flexión

Otro conjunto de aplicaciones de estas estructuras muy representativas se encuentra en el ámbito de las bóvedas, cúpulas y estructuras de techo. Algunas ilustraciones de este último conjunto de aplicaciones puede verse en las Figuras 4, 5 y 6 .

Finalmente, otra aplicación muy interesante de este nuevo concepto de elemento constructivo corresponde a la fabricación de viviendas prefabricadas, gracias a la versatilidad y caracteristicas de estas estructuras sandwich novedosas de tejidos tridimensionales de materiales compuestos.

La Figura 7 ilustra un ejemplo de aplicación de los sandwiches de tejidos tridimensionales en la construcción de una vivienda.

\section{CONCLUSIONES}

Las nuevas estructuras sandwich desarrolladas en materiales compuestos a partir de tejidos tridimensionales, han demostrado con éxito ser alternativas en diferentes campos de aplicación entre

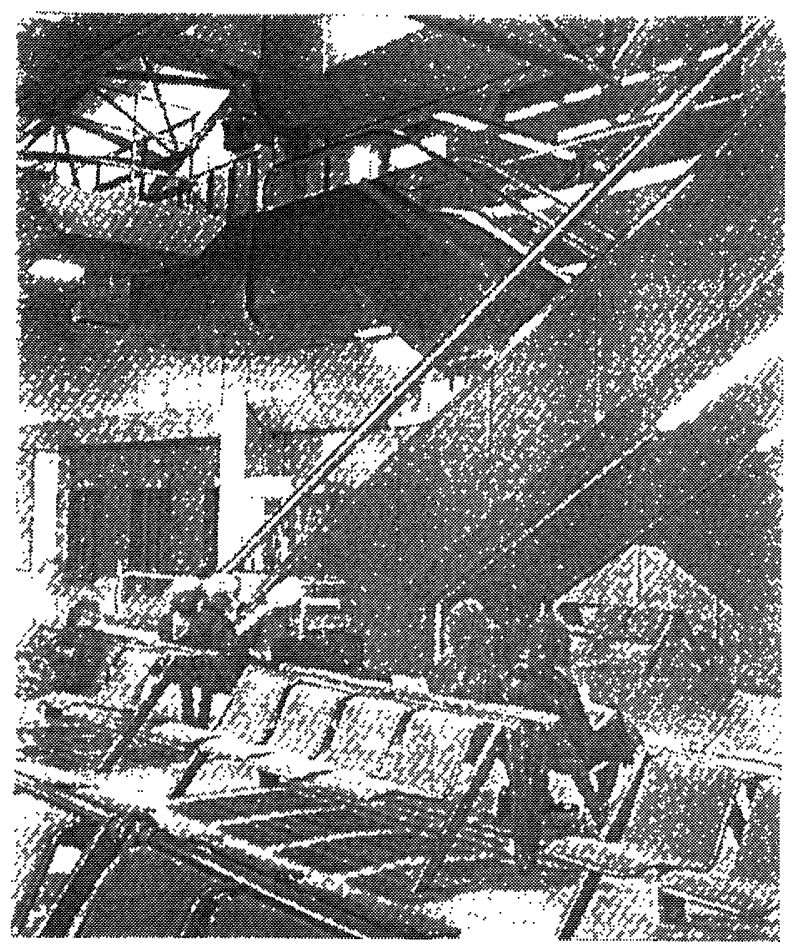

liig. 4.- Interiores del aeropuerto de Heathrow (Londres) realizados am estructuras sandwich.

Fig. 4.- Interior of Heathrow airport (London) made up of sandwich structures.
New 3-D sandwich structures are specially well qualified to produce floors thanks to their outstanding properties in terms of specific rigidity and strength against bending loads.

Other very representative serie of applications are in domes, vaults and ceiling structures. Some pictures of these last series of applications can be seen in Figures 4,5 and 6.

Finally another very interesting application is in prefabricated homes, thanks to their characteristics and versatility. Figure 7 shows an example of application of 3-D sandwich fabrics in the manufacture of a prefabricated dwelling.

Figure 7 shows an example of application of three dimensional fabric sandwich structures on the construction of a house.

\section{CONCLUSTONS}

New sandwich structures developed in composite materials from 3-D fabrics have proved to be successful alternatives in different fields of application, and among them the building sector. This is due to the
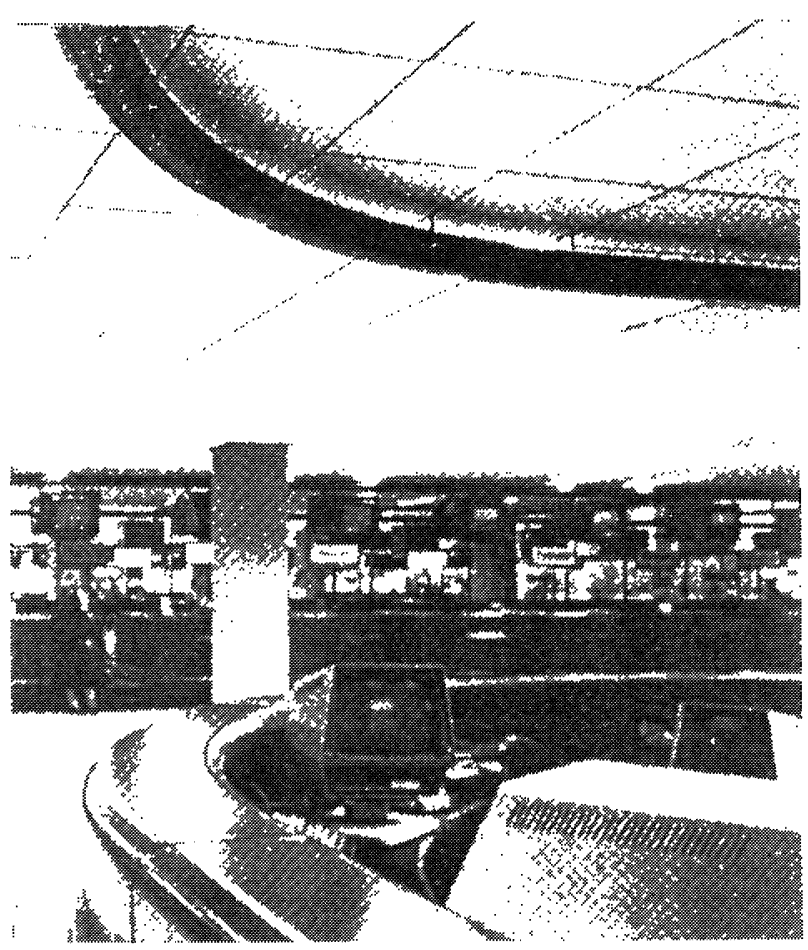

Fig. 5.- Vista general del techodel hall del aeropuertoSchiptol deAmsterdam, realizado con estructuras sandwich.

Fig. 5.- Overall view of the ceiling of a terminal in Schiptol airport (Amsterdam) made up of sandwich structures. 


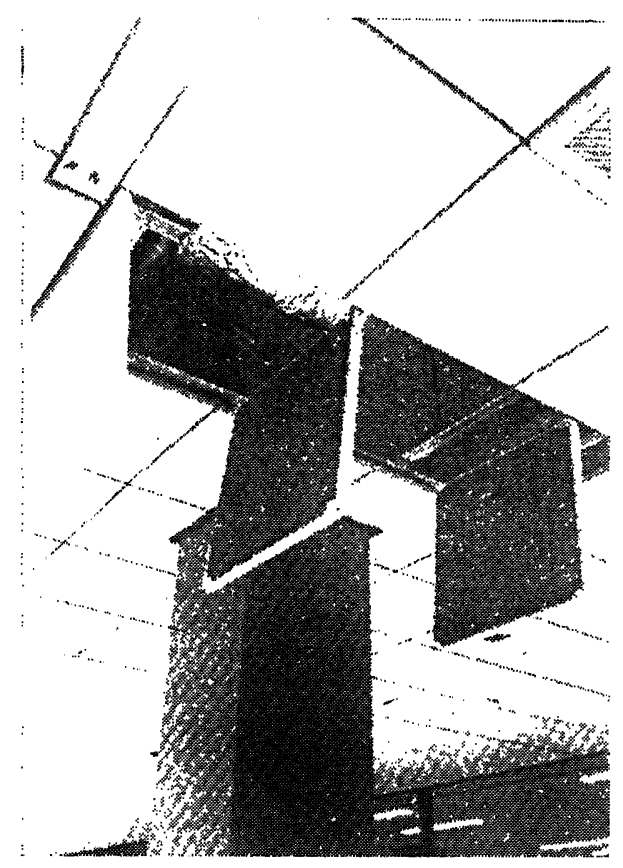

Fig. 6.- Detalle del techo del hall del aeropuerto Schiptol de Amsterdam. realizado con estructuras sumdwich.

Fig. 6.- (.lose view of the ceiling of a terminal in Schiptol airpont (Amsterdam) made up of sandwich structures.

los que, por supuesto, se encuentra el sector de la construcción. Esto es debido a que estas nuevas estructuras sandwich reúnen todas las caracteristicas ventajosas presentadas por las estructuras sandwich tradicionales y, además, son capaces de superar los inconvenientes que se encontraban presentes en las estructuras clásicas, como era su tendencia a la delaminación, aparición de concentración de tensiones ante la existencia de agujeros o uniones atornilladas y baja resistencia al fuego. De modo que son aplicadas en muros, tabiques, bóvedas, cúpulas, estructuras de techo y suelo y viviendas

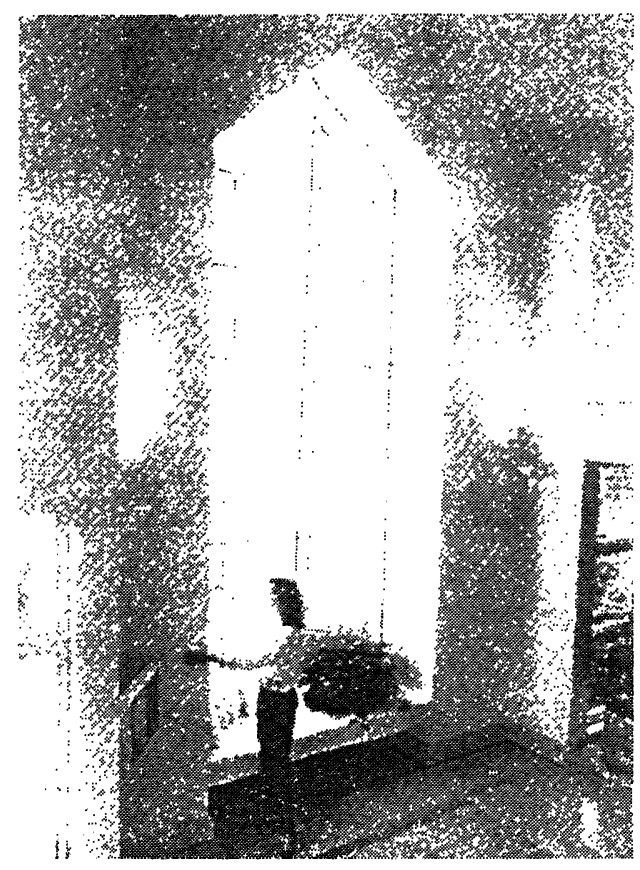

Fig. 7.- Ijecución en paneles sondwich de tejidos tridimensionales en el interior de una vivienda.

Fïg. -. - Sandwich sheets in the interior of a dwelling.

characteristics of these structures added to the advantages of conventional sandwich structures and they are moreover able to overcome some of their drawhacks like tendency towards delamination. concentration stresses in bores and screwed joints and low' fire resistance. They are consequently applied in walls, partitions, domes, vaults, ceiling and floor structures and dwellings.

\section{BIBLIOGRAFÍA}

(1) MIRAVETE A.: “los nuevos materiales en la construccion", pp. 394, 1994.

(2) ANTEQUERA, P., JIMÉNEZ, L., MIRAVETE A.: "Los materiales compuestos de fibra de vidrio", Secretariado de Publicaciones, Universidad de Zaragoza, España, pp. 275, 1993.

(3) BERTHELOT, J. M.: "Matériaux C'omposites, ('omportement Mécanique et Analyse des Structures", Masson. 1992.

(4) CAPRINO, G., TETI, R.: “Sandwich Structures. Handbook”, II Prato, 1989.

(5) CHOU, T., KO, F.: "T'extile Structural ('omposites", Elsevier, 1989.

(6) VERPOEST, I., KO, F., WULFHORST, B., BEUKERS, A.: "Seminair on New T'extiles for ('omposites", Leuven (Belgium), 1991. 